\title{
Oil Price Fluctuation, Monetary Policy and Output Growth in Nigeria
}

\author{
Olowoyo, Boluwatife Wole \\ Graduate Student, Department of Economics, Ekiti State University, Ado-Ekiti, Ekiti State, Nigeria \\ Ogunleye, Edward Oladipo \\ Department of Economics, Ekiti State University, Ado-Ekiti, Ekiti State, Nigeria
}

\begin{abstract}
This study examines the dynamic relationship among Oil Price Fluctuation, Monetary Policy and Output Growth in Nigeria between the periods of 1986 to 2019. Time series data was used for the analysis and Vector Autoregression Model was also employed in this study. The estimation of the VAR showed that Gross Domestic Product growth rate has a negative response to the shocks of foreign interest rate, prime lending rate, real effective exchange rate and output gap but has a positive response to the shocks of oil price volatility and money supply. The result also showed that foreign interest rate has a positive response to real effective exchange rate and a negative response to Oil Price Volatility, Money Supply, Prime Lending Rate and Output Gap. The shocks to the money supply and real effective exchange rate have a positive effect on oil price volatility, whereas the output gap has a negative effect. The study concluded that output gap has a positive response to the shocks of gross domestic product growth rate and prime lending rate but a negative response to the shock of real effective exchange rate and asymmetric response to the shocks of money supply, foreign interest rate and oil price volatility.
\end{abstract}

Keywords: Oil Price Volatility, Monetary Policy, Output Growth, Vector Autoregressive Model, Unit Root Test DOI: $10.7176 / \mathrm{JESD} / 12-24-06$

Publication date: December $31^{\text {st }} 2021$

\section{Introduction}

Crude oil is one of the world's most essential commodities nowadays, as it is a crucial source of energy to many countries of the world. In recent years, economists identified factors that have contributed to oil price fluctuation such as shocks to the supply which arises from political activities and events, revolutions and war in OPEC countries, technology improvement with which crude oil is being extracted and the discovery of new fields (Nagmi, 2016). Fluctuations have occurred in various periods but there are periods whereby the fluctuations were so sharp. The fall in oil prices has posed tolerable defiance for fiscal, monetary and structural policy in different economies. The fluctuations have also been a problem to many countries in aspect of policies making.

In Nigeria, crude oil has received adequate attention. Nigeria has been one of the world's major crude oil exporters since 1958, and it has subsequently developed into a country with a growing gross domestic product (GDP). The growth in GDP can be attributed to the level of oil exported to crude oil importing countries. Rise in the price of crude oil and the resultant growth in the country's revenue created the possibility for development in industries, increased growth in output and improvement of the Nigeria economy.

The fact that there is an over-reliance on crude oil has made Nigeria a mono-cultural economy that depends largely on the revenue that comes from crude oil production to sustain her growing population and the economy so as to foster political, physical and socio-economic development. As reported by CBN (2018), the monetary policy conduct was seriously affected by the global financial crisis in 2008 which began in year 2007 in the United State and expanded to emerging economies including Nigeria. The global financial crisis has serious influence on the output growth of Nigeria due to the diminished demand for crude oil and decline in oil price which led to fall in the external reserves putting more pressure on the inflation and exchange rate as well (CBN, 2018).

The commercial banks in Nigeria have also been playing a crucial role in the development of the Nigeria overtime. According to the World Bank (2015), the Minimum Re-Discounted Rate (MRR) has gone through several fluctuations since 1987 which was after the Structural Adjustment Program began till date and this is as a result of the changes in the Central Bank of Nigeria policies and has changed the economic condition of Nigeria. In August 1987, the MRR was $15.0 \%$ and it was reduced to $12.75 \%$ in December of the same year, with the objective of stimulating and gearing up growth and investment in the economy (World Bank, 2015). Furthermore, the MRR was raised to $13.25 \%$ in 1989 because of the effect of inflation, the rise in MRR was done to further liberalize the management of the interest rate, but unfortunately, the inflationary spiral could not be contained so the cap on interest rate was lifted in 1992 and reinstated in 1994.

In 1986, Nigeria implemented the Structural Adjustment Programme (SAP) and it led to the strict regulation of the commercial banks' lending practice and the regulation is done under banks' supervisory bodies close surveillance. Since 2004, the Monetary Policy Committee (MPC) of the Central Bank of Nigeria usually deliberates on possibility of fixing the Monetary Policy Rate according to the performance of the economy. 
According to the World Bank (2015), in 2004, the Minimum Re-Discounted Rate was 15\% while the Lending Rate was $20 \%$, Saving Rate was $4.9 \%$ and Time Deposit Rate for the same period was $10.8 \%$. In the same view, World Bank (2015) also reported that between the year 2000-2005 the Lending Rate was $21.27 \%$ to $17.95 \%$ while economic growth rate was $7.70 \%$ to $8.68 \%$ respectively. In support, the International Monetary Fund (2016), also reported that between $2010-2016$ the Lending Rate ranged from $17.59 \%$ to $17 \%$ while the economic growth was from $9.97 \%$ to $2.70 \%$. This insinuates that as the bank lending rate decreases, economic growth of the country reduces and this is caused by some underlined factors which the study seek to examine.

More so, it was also revealed by the CBN that the global financial crisis led to liquidity crisis which was a challenge to the monetary authorities. According to the World Bank (2017), Nigeria's output growth decreased from 8.03 percent to 4.23 percent between 2009 and 2012, owing to a drop in oil prices and a drop in foreign reserves, putting pressure on inflation and the exchange rate. With the continued fall in oil price, the monetary policy committee sustained the tight monetary policy stance from 2012 through to 2013 and there was an increase in Nigeria's Gross Domestic Product (GDP) growth rate from 4.23 percent in 2012 to 6.67 percent in 2013 (World Bank, 2019). UNCTAD (2019) also reported that, the Nigeria's GDP contracted by 1.6 percent in 2016 due to the hard hit by the global oil price collapse of 2014/2015. In 2014, the GDP growth rate was drastically reduced as a result of the drop in crude oil prices and the depletion of foreign exchange reserves, putting severe pressure on the exchange rate, which pushed midpoint from N155/US\$ to N168/US\$. Decreasing global oil prices, along with lesser demand for Nigeria's crude oil overseas, resulted in lower foreign reserve accumulation and also put exchange rate under pressure, causing a drastic reduction in the GDP growth rate of Nigeria from 6.30 percent in 2014 to 2.65 percent in 2015 and -1.61 percent in 2016 (CBN, 2016). This led to a downturn in economic activities and resulted in recession.

There are many studies on the effects of oil price fluctuation on monetary policy indicators in Nigeria. While some studies (Rubina 2017; Robert and Lutz 2004; Kipil and Shine 2013) exerted a negative impact of crude oil price change on monetary policy indicators, while some studies showed a positive impact (Terfa 2016; Aliyu 2009; Olomola and Adejumo 2006) and some other studies showed that crude oil price change exert a significant effect on monetary policy indicators (Juncal and Fernando 2004; Peter 2011). Some studies have also empirically investigated the effect of the volatility in the price of crude oil on output growth of Nigeria. Some studies (Nwoba and Abah 2017; Katrakilidis, Lake and Mardas 2010; Mohammed and Gunther 2008; Nagmi 2016; Mehrara and Mohaghegh 2011; Hilde 2008) exerts that oil price change has positive influence on output growth, other studies like (Adeleke and Harold 2014; Joao 2009; Moayad and Mutafa 2016; Miguel 2003) exerts a negative impact of crude oil change on output growth. However, while some of the studies established significant impact of crude oil change on output growth (Cunado and Gracia 2004; Tura 2016; Ishmael, Matthew and Park 2017), others found insignificant impact (Olomola 2006; Adeleke and Ngalawa 2016; Chuku, Effiong and Sam 2010). This has been a knowledge puzzle to scholars in reaching a conclusion on the effect and relationship between oil price volatility and output growth.

Some other studies focused on the impact of monetary policy stance on output growth. Studies like (Charles 2012; Imoughele and Ismaila 2014; Manouchehr and Ahmad 2011; Rafiq and Mallick 2008) exerted a positive relationship between monetary policy and output growth, while some other studies exerted a negative impact (Ogunmuyiwa and Ekone 2010; Arshad and Tariq 2009). There are some studies that concluded that the impact of monetary policy on output growth is significant (Osasohan 2014; Chipote and Makhetha-Kosi 2014; Kim 2014) and some others exerted a negative impact (Mohsen and Maysam 2011; Mutuku and Koech 2014).

It could be concluded that previous studies are faced with many controversies and inconclusiveness. This is as a result of the fact that previous empirical studies failed indicating the clear cut relationship (positive or negative) between the variables. In addition to this, the omission of some important variables that should be included in their estimation is not done. Therefore, this study intends to add foreign variables such as the foreign interest rate (proxy by the United State interest rate) to domestic variables so as to have a robust result. In addition, none of the previous studies ascertain the dynamic interaction among oil price fluctuation, monetary policy shocks and output growth in Nigeria. In the light of the above issues, this study specific objective is to look at the dynamic interaction among oil price fluctuation, monetary policy and output growth in Nigeria.

\section{Theoretical Review}

\section{The linear/ Symmetric relationship theory of economic growth}

This theory has been widely used by different researchers such as Hamilton (1983); Goodwin (1985); Laser (1987); Gisser (1985); and Hooker (1986). The members of this school postulated that the Gross Domestic Product growth is being driven by the volatility of oil price. Their theory is being hinged on the happenings in the oil market between the year 1948 and 1972 and the effect it has on oil importing and oil exporting economies. Hooker (2002) studies showed that between the year 1948 and 1972 oil price changes determined and influenced the growth of gross domestic product significantly. Laser (1987), who later joined the symmetric school of thought, also confirmed the linear relationship between economic growth and oil price volatility. After she empirically studied 
the subjects, she came to the conclusion that a rise (reduction) in oil prices will result in a drop (increase) in gross domestic product, whereas the effect of an oil price fall on gross domestic product is ambiguous due to the various effects in different nations.

\section{Renaissance growth theory}

This theory attempt to differentiate between oil price change and oil price volatility. The theory/model was an off shoot of the symmetry and asymmetry in effect school which was led by Lee (1998). Volatility is defined as the standard deviation in a given period (Lee, 1998). She concluded that oil price change and oil price volatility have negative impacts on economic growth but in divers' ways. She claims that oil price volatility has a negative and large influence on economic growth with an immediate effect, whereas the impact of oil price changes takes a year to manifest. She ultimately finished by stating that the volatility of crude oil prices, not the level of crude oil prices, has a substantial impact on economic growth.

\section{Empirical Review}

Apere (2017) used quarterly data from 1980:1 to 2015:4 to experimentally analyze the relationship between oil price variations and inflation in Nigeria. The study employed the Vector Autoregressive Model as the econometric tool to evaluate data from the Central Bank of Nigeria (CBN) and the Energy Information Administration (EIA). According to the study, inflation responds to oil price fluctuations by falling when oil prices fall, and a constant and positive oil price results in a consistent negative inflation rate. According to the findings, there is a negative association between inflation and oil price fluctuations.

Margaret Adeniyi and Osaretin (2012) explored the oil price pass-through into inflation in Nigeria empirically. A conventional pass-through equation in the form of an Autoregressive Distributed Lag (ARDL) model was utilized in the study, and a quarterly series from 1990 to 2010 was used for the estimate. Changes in the price of oil have had a major impact on inflation, according to the results of the estimation. Exchange rate movements, changes in the broad money supply, and changes in the maximum lending rate all influenced inflation, according to the study.

Between 1970 and 2013, Victor (2015) investigated the impact of oil revenue on Nigerian industrial growth. He tested stationarity with an ADF test, and all variables were integrated at first difference. The Johansen cointegration test also shows that oil income growth has a long-term positive impact on Nigeria's industrial growth. The coefficient of error correction term is small, according to VEC estimations.

Using data from 1960 to 2010, Nwoba and Abah (2017) investigated the impact of crude oil revenue on Nigerian economic growth. For the regression analysis, they used the Ordinary Least Square (OLS) approach. According to the research, crude oil has a major impact on Nigeria's economic growth. The study also discovered that international oil firms have had a substantial impact on Nigeria's economic growth through operations such as oil processing, licensing production, oil consumption, and crude oil export. According to the report, crude oil revenues and international oil corporations in Nigeria have had a beneficial and considerable impact on Nigeria's economic growth and development.

With the time series 1980 to 2011, Michael and Ebibai (2014) investigated the impact of monetary policy on selected macroeconomic variables in Nigeria. To determine if there is a static long run equilibrium relationship among the explanatory variables and then drive a suitable dynamic model of the short run relationship, an econometric method such as the Ordinary Least Square was used. According to the report, creating an investmentfriendly atmosphere in the Nigerian economy will boost the country's GDP growth rate (GDP).

Olomola (2006) investigated the impact of oil price shocks on Nigerian output, inflation, real exchange rate, and money supply. He analyzed quarterly data from 1970 to 2003 . The data was analyzed using the vector autoregression approach. The study's findings showed that oil price shocks had no significant impact on Nigeria's output and inflation rate throughout the time period studied. The research also showed that fluctuations in oil prices had a significant impact on Nigeria's real exchange rates. The study also discovered that the changes in aggregate economic activity proxy, GDP, are influenced by the oil price's expression in real exchange rates and money supply, rather than the oil price itself. The study indicated that a high real oil price can cause a wealth effect, which raises the real exchange rate and squeezes the tradable sector, resulting in the "Dutch Disease Syndrome."

\section{Methodology}

Theoretical Framework

The theoretical framework of Mundel-Flemming-Tobin model which was described by Asbjorn Rødseth (2000) in his book "Open Economy Macroeconomy) was adopted by this study. The theoretical framework captures the fiscal and monetary policy in a standard open economy and also their mechanisms. IS-LM framework is revised by the model where consumption $(\mathrm{C})$, private investment $(\mathrm{I})$, government consumption and expenditure $(\mathrm{G})$, and the net export (export-import represented by " $\mathrm{X}$ " which is the function of risk premium " $\mathrm{R}$ ", national income " $\mathrm{Y}$ ", and the return from foreign investment $\mathrm{Y}^{*}$ ) 


\section{Model Specification}

Generally, the economic model specification is based on the theoretical framework. This study adapts the model with some modifications on the available data relating to oil price fluctuation, the variable of monetary policy and also the variable of output growth. The data for this study is secondary data sourced from the World Development Indicator (WDI), International Monetary Fund World Economic Outlook Statistical Bulletin and Central Bank of Nigeria Statistical Bulletin, spanning from 1986 to 2019. The variables are Gross Domestic Product, Output Gap, Prime Lending Rate, Foreign Interest Rate proxy with the US interest rate, Money Supply, Real Effective Exchange Rate and World Oil Price.

RGDP $=(\mathrm{MS}, \mathrm{PLR}, \mathrm{REER}, \mathrm{FINT}, \mathrm{OPG}, \mathrm{OPV}, \mathrm{WOP})$

Where RGDP is Real Gross Domestic Product, MS is Money Supply (Broad), PLR is Prime Lending Rate, REER is Real Effective Exchange Rate, FINT is Foreign Interest Rate, OPG is Output Gap, OPV is Oil Price Volatility and WOP is World Oil Price. Hence, the model can be re-written as:

$R G D P_{t}=\beta_{0}+\beta_{1} M S_{t}+\beta_{2} \mathrm{PLR}_{t}+\beta_{3} \mathrm{REER}_{t}+\beta_{4} \mathrm{FINT}_{t}+\beta_{5} \mathrm{OPG}_{t}+\beta_{6} O P V+\beta_{7} \mathrm{WOP}_{t}+\mu_{t}$

\section{Analysis, Estimation and Results}

To determine the stationarity of the variables, the researchers used the Augmented Dickey-Fuller (ADF) test with a constant and linear trend. Table 1 displays the results of the ADF test.

Table 1: Unit Root Test

\begin{tabular}{|l|l|l|l|l|l|}
\hline \multirow{4}{*}{ Variables } & \multicolumn{7}{|l|}{ Augmented Dickey-Fuller Test } \\
\cline { 2 - 6 } & At Level & At First Difference & \\
\cline { 2 - 6 } & t-statistics & P-value & t-statistics & P-value & Order of Integration \\
\hline GDPGR & -3.564572 & 0.0078 & & & $\mathrm{I}(0)$ \\
\hline FINT & -1.667372 & 0.4455 & -11.50928 & 0.0000 & $\mathrm{I}(1)$ \\
\hline MS & -3.130908 & 0.0266 & & & $\mathrm{I}(0)$ \\
\hline PLR & -2111975 & 0.2404 & -5.951007 & 0.0000 & $\mathrm{I}(1)$ \\
\hline OPG & -3099693 & 0.0289 & & & $\mathrm{I}(0)$ \\
\hline REER & 1.067463 & 0.9971 & -3.579485 & 0.0074 & $\mathrm{I}(1)$ \\
\hline WOP & -1.408751 & 0.5764 & -11.52021 & 0.0000 & $\mathrm{I}(1)$ \\
\hline
\end{tabular}

Source: Author's Computation, 2021

From Table 1, the ADF test indicate that Gross Domestic Product growth rate (GDPgr), Money Supply (MS), and Output Gap (OPG) is stationary at level I(0), while Foreign Interest Rate (FINT), Prime Lending Rate (PLR), Real Effective Exchange Rate (REER) and World Oil Price (WOP) are stationary at first difference I(1).

\section{Vector Autoregressive Model}

Fig 1: Impulse Response of Oil Price Volatility, Monetary Policy Variables and Output Growth.
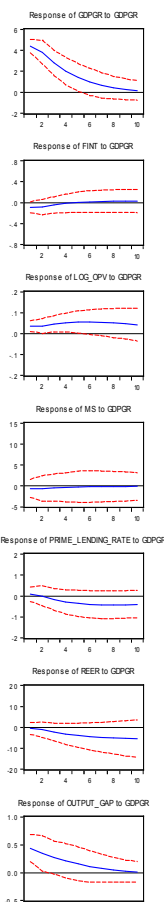
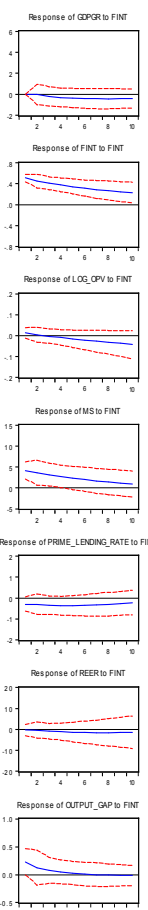
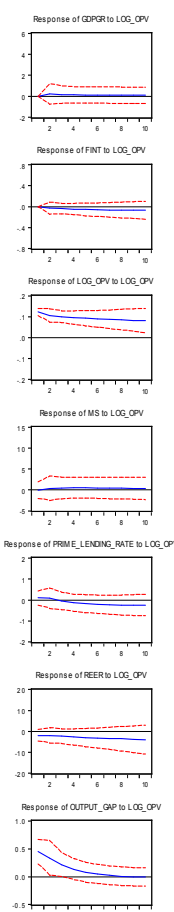
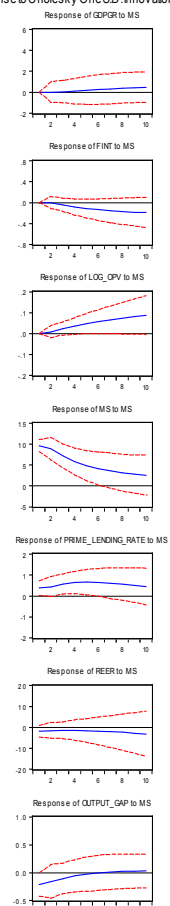
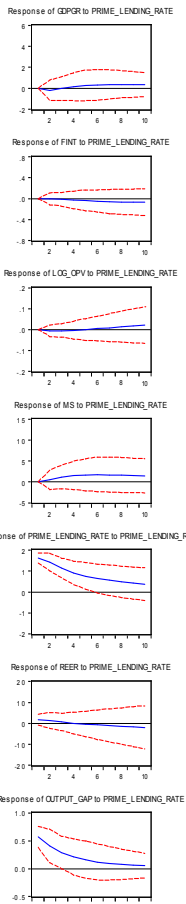
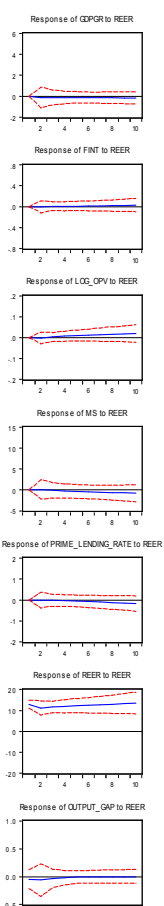
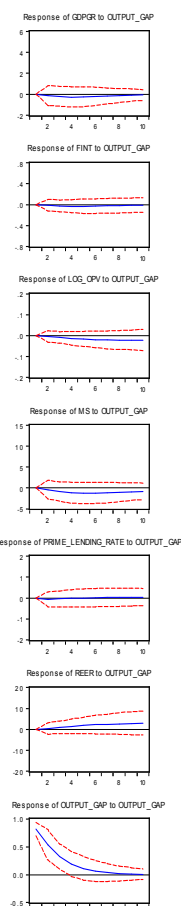
It is observed that GDPgr (gross domestic product growth rate) responded positively to its own shock, the positive response of gross domestic product to its own shock declines continuously from the first period to the tenth period. This means that shocks to gross domestic product had a positive impact on itself in the short-run and on the long-run. Gross domestic product had a negative response to foreign interest rate and remained in the negative region from the first period to the tenth period which implies that gross domestic product had a negative impact on foreign interest rate in the short-run and on the long-run. It was also indicated that impulse response function of gross domestic product growth rate maintained a steady state value and a positive response to the oil price volatility from the first period to the tenth period.

According to the analysis gross domestic product maintained a constant rising and a positive response to money supply from the first period to the tenth period and it means that gross domestic product has a positive impact on money supply in the short-run and on the long-run. Gross domestic product initially has a negative response to prime lending rate from the first period to the third period and started rising from the steady state in the fourth period leaving the negative region to the positive region, the steady state was maintained from the sixth period to the tenth period and this implies that the gross domestic product had asymmetric impact on prime lending rate in the short-run and on the long run. The response of gross domestic product to real effective exchange rate and OPG (output gap) is negative throughout the owe period which means in the short-run and on the long-run, gross domestic product had a negative impact on real effective exchange rate and output gap.

In the same Figure the response of foreign interest rate to gross domestic product is negative from period one to period four having rising from the negative region to the positive region and stayed at the positive region from period four to the tenth period, this means foreign interest rate had an asymmetric impact on gross domestic product in the short-run and on the long-run. Foreign interest rate responded positively to its own shock but the response gradually declines from the first period to the tenth period which shows that foreign interest rate had a positive impact on its shock in the short-run and on the long-run. The response of foreign interest rate to oil price volatility is negative and remained in the negative zone from the first period to the tenth period maintaining a steady state value, meaning that foreign interest rate had a negative impact on oil price volatility in the short-run and on the long-run and this is the same situation in the response of foreign interest rate to the shocks of money supply, prime lending rate and output gap. The response of foreign interest rate to the shock of real effective exchange rate is positive and remained in the positive region from the first period to the tenth period. This implies that foreign interest rate had a positive impact on real effective exchange rate in the short-run and on the long-run.

The response of oil price volatility to gross domestic product, money supply, oil price volatility, and real effective exchange rate is positive. This means that oil price volatility will have a positive impact on gross domestic product, money supply, oil price volatility and real effective exchange rate in the short-run and on the long-run but has a negative impact on output gap and asymmetric impact on foreign interest rate and prime lending rate in the short-run and on the long-run. The response of MS to the shock of gross domestic product, real effective exchange rate and output gap is negative and the response to the shock of foreign interest rate, oil price volatility, money supply, and prime lending rate is positive. This implies that money supply had a negative effect on gross domestic product, real effective exchange rate, and output gap in the short-run and the long-run while money supply had a positive impact on foreign interest rate, oil price volatility, money supply and prime lending rate in the short-run and on the long-run.

The response of prime lending rate to the shock of gross domestic product, oil price volatility and output gap is asymmetric. The response of prime lending rate to the shock of foreign interest rate and real effective exchange rate is negative while the response of prime lending rate to the shock of money supply and prime lending rate is positive. This indicate that prime lending rate had an asymmetric effect on gross domestic product, oil price volatility and output gap on the long-run and in the short-run. The effect of prime lending rate on foreign interest rate and real effective exchange rate is negative and the effect of prime lending rate on prime lending rate and money supply is positive in the short-run and on the long-run. The response of real effective exchange rate to shocks gross domestic product, foreign interest rate, oil price volatility and money supply is negative while the response of real effective exchange rate to its shock and that of output gap is positive. The response real effective exchange rate to the shock of prime lending rate is asymmetric. This indicate that real effective exchange rate had a negative impact on gross domestic product, foreign interest rate, oil price volatility and money supply and a positive impact on its real effective exchange rate and output gap, also an asymmetric effect on prime lending rate in the short-run and on the long-run.

The response of output gap to the shock gross domestic product is in the positive region though declining from the first period to the tenth period and it is the same with the shocks of prime lending rate and output gap itself but has an asymmetric response for others except for real effective exchange rate which is rising towards the positive zone but still negative till the tenth period. This means that output gap will have a positive effect on gross domestic product, prime lending rate and output gap, it also had an asymmetric effect on the foreign interest rate, money supply and oil price volatility. The effect output gap had on real effective exchange rate is negative in the short-run and on the long-run. 


\section{Variance Decomposition}

Table 2

\begin{tabular}{|l|l|l|l|l|l|c|c|c|}
\hline \multicolumn{2}{|l|}{ Variance Decomposition of GDPgr } \\
\hline Period & S.E. & GDPgr & FINT & LOG_OPV & MS & PLR & REER & OPG \\
\hline 1 & 4.391432 & 100.0000 & 0.000000 & 0.000000 & 0.000000 & 0.000000 & 0.000000 & 0.000000 \\
\hline 5 & 6.947532 & 98.21103 & 0.626811 & 0.155903 & 0.063663 & 0.261582 & 0.192627 & 0.488389 \\
\hline 10 & 7.235373 & 93.53771 & 2.489129 & 0.212311 & 1.336379 & 1.241185 & 0.461288 & 0.721994 \\
\hline
\end{tabular}

Source: Author's Computation, 2021

Table 2 revealed that gross domestic product account for all (100 percent) it forecast error variance in the first period and its influence reduced slightly in the medium term which is the fifth period to 98.21 percent and further decrease till the tenth period accounting for $93.53 \%$ which is the long term. Other variables do not give explanation to the variation in gross domestic product in the first period. The result of the analysis showed that influence of foreign interest rate in the explanation of the variation in gross domestic product increases from $0.62 \%$ in the medium term which is the fifth period to $2.48 \%$ in the long term which is the tenth period. It is evident that foreign interest rate and other variables including oil price volatility, money supply, prime lending rate, real effective exchange rate and output gross account for a minute portion of gross domestic product shocks forecast error variance in the short, medium and long term.

Table 3:

\begin{tabular}{|l|l|l|l|c|c|c|c|c|}
\hline \multicolumn{2}{|l|}{ Variance Decomposition of FINT } \\
\hline Period & S.E. & GDPgr & FINT & LOG_OPV & MS & PLR & REER & OPG \\
\hline 1 & 0.516894 & 3.324358 & 96.67564 & 0.000000 & 0.000000 & 0.000000 & 0.000000 & 0.000000 \\
\hline 5 & 0.967646 & 2.049775 & 93.88340 & 0.903267 & 2.428701 & 0.309574 & 0.008592 & 0.416690 \\
\hline 10 & 1.220057 & 1.454098 & 83.15925 & 2.105342 & 11.20171 & 1.546108 & 0.099833 & 0.433660 \\
\hline
\end{tabular}

Source: Author's Computation, 2021

Table 3 showed that foreign interest rate account for 96.67 percent for it forecast error variance in the first period and gross domestic product accounted for 3.32 percent in the same period where other variables did not give any explanation to the variation in foreign interest rate in the first period. Foreign interest rate and gross domestic product reduced in the medium term and long term from 93.88 percent to 83.15 percent and 2.04 percent to 1.45 percent respectively. Oil price volatility, money supply and prime lending rate increased in the medium and long term from 0.9 percent to 2.1 percent, 2.42 percent to 11.2 percent, 0.3 percent to 1.54 percent. Real effective exchange rate and output gap did not give any explanation to the variation of foreign interest rate throughout the period, that is the short, medium and long term.

Table 4:

\begin{tabular}{|l|c|l|l|l|l|l|l|c|}
\hline \multicolumn{2}{|l|}{ Variance Decomposition of LOG_OPV } \\
\hline Period & S.E. & GDPgr & FINT & LOG_OPV & MS & PLR & REER & OPG \\
\hline 1 & 0.127389 & 7.361205 & 0.936159 & 91.70264 & 0.000000 & 0.000000 & 0.000000 & 0.000000 \\
\hline 5 & 0.261904 & 14.76872 & 0.764567 & 77.28438 & 5.943945 & 0.108761 & 0.192434 & 0.937194 \\
\hline 10 & 0.391585 & 14.50799 & 4.070658 & 57.96555 & 20.04140 & 0.660796 & 0.857344 & 1.896266 \\
\hline
\end{tabular}

Source: Author's Computation, 2021

Table 4 revealed that oil price volatility account for 91.7 percent of it forecast error variance in the first period while gross domestic product accounted for 7.36 percent, other variables did not account for any explanation to the variation of oil price volatility in the first period. In the medium term which is the fifth period the explanation of oil price volatility to it variation reduced to 77.28 percent while that of gross domestic product and money supply increased to 14.76 percent and 5.94 percent while other variables did not account for the explanation of the variation to oil price volatility in the medium term. Oil price volatility explanation to its variable further reduced in the tenth period to 57.96 percent, remained 14 percent and foreign interest rate, money supply and output gap explanation to the variation of oil price volatility increased to 4 percent, 20 percent and 1.89 percent respectively in the long term. Prime lending rate and real effective exchange rate did not have any explanation to the variance of oil price volatility throughout the periods.

Table 5:

\begin{tabular}{|l|l|l|l|l|l|l|l|l|}
\hline \multicolumn{7}{|l|}{ Variance Decomposition of MS } \\
\hline Period & S.E. & GDPgr & FINT & LOG_OPV & MS & PLR & REER & OPG \\
\hline 1 & 10.49720 & 0.372072 & 15.25909 & 0.011083 & 84.35776 & 0.000000 & 0.000000 & 0.000000 \\
\hline 5 & 18.51343 & 0.374939 & 15.13241 & 0.216864 & 81.09730 & 1.868331 & 0.080629 & 1.229525 \\
\hline 10 & 20.66827 & 0.350978 & 14.56024 & 0.328681 & 77.37801 & 4.389931 & 0.618671 & 2.373491 \\
\hline
\end{tabular}

Source: Author's Computation, 2021

Table 5 indicated that MS account for 84.35 percent for it forecast error variance in the first period and it reduced in the fifth period to 81 percent, it further reduced in the tenth period to 77.3 percent. Other variable did 
not have any explanation to the variation of money supply in the first period except for gross domestic product, foreign interest rate and oil price volatility which account for 0.37 percent, 15.25 percent and 0.01 percent respectively. Gross domestic product, foreign interest rate, oil price volatility, money supply, prime lending rate, real effective exchange rate and output gap explained 0.37 percent, 15.13 percent, 0.21 percent, 1.8 percent, 0.08 percent and 1.22 percent of the variation of money supply respectively. Foreign interest rate explanation of the variation to money supply reduced in the tenth period to 14.56 percent compared to that of the fifth period which is the medium term. Prime lending rate and output gap account for 4.38 and 2.37 percent in the explanation of the variation of money supply in the long term which is the tenth period.

Table 6:

\begin{tabular}{|l|l|l|l|l|l|l|l|l|}
\hline \multicolumn{2}{|l|}{ Variance Decomposition of PLR } \\
\hline Period & S.E. & GDPgr & FINT & LOG_OPV & MS & PLR & REER & OPG \\
\hline 1 & 1.690513 & 0.250130 & 3.188132 & 0.316499 & 4.794595 & 91.45064 & 0.000000 & 0.000000 \\
\hline 5 & 3.109744 & 2.570687 & 6.252456 & 0.752371 & 15.17079 & 75.11151 & 0.057881 & 0.084308 \\
\hline 10 & 3.765036 & 7.986534 & 7.535459 & 2.570619 & 21.19364 & 59.95302 & 0.676233 & 0.084491 \\
\hline
\end{tabular}

Source: Author's Computation, 2021

Table 6 showed that prime lending rate account for 91.45 percentage for it forecast error variance in the first period and it reduced in the fifth period to 75.11 percent and also in the tenth period to 59.95 percent. Where gross domestic product, foreign interest rate, oil price volatility and money supply accounted 0.25 percent, 3.18 percent, 0.31 percent and 4.79 percent in the explanation of the variation of prime lending rate in the first period. Other variables such as real effective exchange rate and output gap does not have any explanation for the variation of prime lending rate error in the first period. Gross domestic product, foreign interest rate, oil price volatility, money supply and real effective exchange rate increased the percentage of explanation of prime lending rate's error in the fifth period and also the tenth period but output gap remains the same for the fifth period and the tenth period giving 0.08 percent in the medium term and the long term as well.

Table 7:

\begin{tabular}{|l|l|l|l|l|l|l|l|l|}
\hline \multicolumn{2}{|l|}{ Variance Decomposition of REER } \\
\hline Period & S.E. & GDPgr & FINT & LOG_OPV & MS & PLR & REER & OPG \\
\hline 1 & 13.29371 & 0.221060 & 0.065591 & 2.146968 & 2.025126 & 1.605672 & 93.93558 & 0.000000 \\
\hline 5 & 28.35759 & 4.193824 & 0.579570 & 3.805452 & 1.608798 & 0.614571 & 88.43968 & 0.758104 \\
\hline 10 & 43.91217 & 8.494034 & 0.865956 & 5.087117 & 2.327341 & 0.839164 & 80.32711 & 2.059282 \\
\hline
\end{tabular}

Source: Author's Computation, 2021

Table 7 explained that real effective exchange rate explained 93.93 percent for it forecast error variance in the first period but had a reduced percentage of its explanation in the medium term and the long term which is 88.43 percent and 80.32 percent respectively. Other variables had a non-significant percentage that explains the forecast error variance of real effective exchange rate in the first period where output gap had no bit explanation. In the medium term, other variables increased the percentage of the explanation of forecast error variance except for money supply and which reduced from 2.02 percent in the first period to 1.6 percent in the medium term and 1.6 percent in the first period to 0.61 percent in the fifth period respectively. In the long term which is the tenth period all other variable increased in the percentage at which they explain the variance error of the real effective exchange rate except for real effective exchange rate itself.

Table 8:

\begin{tabular}{|l|l|l|l|l|l|l|l|l|}
\hline \multicolumn{7}{|l|}{ Variance Decomposition of OPG } \\
\hline Period & S.E. & GDPgr & FINT & LOG_OPV & MS & PLR & REER & OPG \\
\hline 1 & 1.215149 & 12.96198 & 3.584645 & 13.60236 & 3.125008 & 21.80632 & 0.161384 & 44.75831 \\
\hline 5 & 1.649473 & 16.42370 & 2.804918 & 13.90423 & 3.234240 & 23.21484 & 0.308711 & 40.10936 \\
\hline 10 & 1.668868 & 16.77495 & 2.771795 & 13.66912 & 3.232525 & 23.87994 & 0.302927 & 39.36874 \\
\hline
\end{tabular}

Source: Author's Computation, 2021

Table 8 revealed that output gap account for 44.75 percent of it forecast variance error in the first period. Gross domestic product, foreign interest rate, oil price volatility, money supply, prime lending rate and real effective exchange rate account for 12.96 percent, 3.58 percent, 13.6 percent, 3.12 percent, 21.8 percent and 0.16 percent respectively in the first period. Some of the variables such as foreign interest rate and oil price volatility 
had a slight reduction in the percentage at wish they explain the variance error in output gap in the medium term and the long term. In the same light some variables such as gross domestic product and prime lending rate had a slight increase in the percentage at which they explain the forecast variance error of output gap while others are the same in the medium term and the long term. this study also employed Vector Autoregression to assess the dynamic interaction among oil price fluctuation, monetary policy variables and output growth in Nigeria. The result of the estimation showed that gross domestic product growth rate has a positive response to the shock of oil price, money supply and its own shock while it has a negative response to the shock of foreign interest rate, real effective exchange rate and output gap but an asymmetric effect to prime lending rate in the short run and on the long run. The result of the positive response of GDPgr to Oil price volatility supports the study of Okoli, et al, (2018); and the positive relationship with money supply negates the study of Ogunmuyiwa and Ekone (2010), that found a negative response of GDPgr to Money Supply. The response of the foreign interest rate to its own shock and that of real effective exchange rate is positive while the its response to the shocks of oil price fluctuation, money supply, prime lending rate and output gap is negative. The response of foreign interest rate to gross domestic product growth rate is asymmetric. The response of oil price to the shocks of gross domestic product growth rate, money supply, real effective exchange rate is positive while reverse is the case for output gap. The response to the shocks of foreign interest rate and prime lending rate is asymmetric in the short run and on the long run.

Money supply has a positive response to its own shock and the shocks of foreign interest rate and oil price fluctuation but the opposite is the case for its response to the shocks of gross domestic product growth rate, real effective exchange rate and output gap. Prime lending rate has a positive response to its own shock and the shock of money supply, but a negative response to the shocks of foreign interest rate and real effective exchange rate. The response of prime lending rate to the shocks of gross domestic product growth rate, oil price fluctuation and output gap is asymmetric.

Real effective exchange rate has a positive response to its own shock and also to the shock of output gap, having a negative response to the shocks of gross domestic product growth rate, oil price fluctuation and money supply. The response of real effective exchange rate to the shock of prime lending rate is asymmetric. Output gap has a negative response to the shock of real effective exchange rate, and a positive response to the shocks of gross domestic product growth rate, prime lending rate and its own shock as well. The response of output gap to the shocks of foreign interest rate, money supply and oil price fluctuation is asymmetric.

\section{Conclusion}

The estimation revealed that output growth responded positively to the shocks of oil price fluctuation and money supply in Nigeria which implies that an increase in the price of crude oil will increase output growth and an increase in money supply with also increase output growth. It was also observed that foreign interest rate and real effective exchange rate has a negative impact on the output growth of Nigeria which means that an increase in the foreign interest rate and real effective exchange rate will lead to a decrease in the output growth of Nigeria. More so, the response of output growth to the shocks of prime lending rate is asymmetric.

It is therefore concluded in this study that reliance on crude oil as a source of revenue in Nigeria serves as an addition in the short run but not enough source of revenue on the long run because it will cause a reduction in the output growth of the economy on the long run which will cause a non-palatable situation to the economy of Nigeria.

\section{Recommendations}

Alternative sources of revenue such as agriculture and investment in technology are some of the sufficient measures to compensate and offset any negative effects from the fluctuation in global oil price. Reviving and building of more refineries will also be a way out to increase the output growth of Nigeria in terms of employment, reduction in the importation of commodities such as refined oil, which will help the balance of payment and the diversion of funds to increase productivity in the country.

\section{References}

Adeleke O. \& Ngalawa, H., (2014). Oil Revenue and Manufacturing Sector Growth in Africa's Oil Exporting Countries. Journal of Economic and Financial Science, 7(3), 925-944.

Adeniyi O. Adenuga, Margaret J. Hilili \& Osaretin O. Evbuomwan, (2012). Oil Price Pass- Through into Inflation: Empirical Evidence from Nigeria. Central Bank of Nigeria Economic and Financial Review Volume 50/1.

Apere ThankGod Oyinpreye, (2017). Crude Oil Price Fluctuation and Inflation in Nigeria. Advances in Social Science Research Journal.

Arshad Hasan \& M. Tariq Javed, (2009). An Empirical Investigation of the Causal Relationship Among Monetary Variable and Equity Market Returns. The Labor Journal of Economics 14: 1(Summer 2009): PP. 115-137.

CBN Education in Economics Series, No. 2, 2016.

Central Bank of Nigeria (2018), Annual Report.

Charles Onyeiwu, (2012). Monetary Policy and Economic Growth of Nigeria. Journal of Economics and 
Sustainable Development.

Chipote Precious \& Makhethat-Kosi Palesa, (2014). Impact of Monetary Policy on Economic Growth: A Case Study of South Africa. Mediaterranean Journal of Social Science, Vol 5, No. 15.

Chuku A. Chuku, Ekpono L. Effiong \& Ndifreke R. Sam, (2010). Oil Price Distortion and their Short and Longrun Impacts on the Nigerian Economy. Munich Personal RePEc Archive.

Hamilton J., (1983). Oil and the Macroeconomy Since World War II. Journal of Political Economy. 91:228-248.

Hilde C. Bjornland, (2008). Oil Price Shock and Stock Market Booms in an Oil Exporting Country. Norwegian School of Management (BI) and Norges Bank.

Ishmael Ogboru, Matthew Terry Rivi \& Park Idisi, (2017). The Impact of Changes in Crude Oil Prices on Economic Growth in Nigeria. Journal of Economics and Sustainable Development.

Joao Tovar Jalles, (2009). Do Oil Price Matter? The Case of a Small Open Economy. Annals of Economics and Finance 10-1, 65-87.

Juncal Cunado \& Fernando Perez de Gracia, (2004). Oil Prices, Economic Activity and Inflation: Evidence for Some Asian Countries. Working Paper No. 06/04.

Kapil Jain \& Shine David, (2013). Crude Oil Prices and Its Role in Economy. IJMIE Volume 3, Issue 11. ISSN: 2249-0558.

Kim Soyoung (2014). Effects of Monetary Policy Shocks on Exchange Rate in the Republic of Korea: Capital Flows in Stock and Bond Markets. Asian Development Review. MIT Press.

Manouchehr Nouri \& Ahmad Jafari Samimi, (2011). The Impact of Monetary Policy on Economic Growth in Iran. Middle-East Journal of Scientific Research. 9(6): 740-743.

Michael Baghebo \& Ebibai Tombra Stephen, (2014). Monetary Policy and Economic Growth in Nigeria. Asian Economic and Financial Review, 2014, 4(1):20-32.

Moayad Al Rasasi \& Mustafa Yilmaz, (2016). The Effects of Oil Shocks on Turkish Macroeconomic Aggregates. International Journal of Energy Economics and Policy, 6 (3), 471-476.

Mohammad Reza Faranegan \& Gunther Markwardt, (2008). The Effect of Oil Price Shocks on the Iranian Economy. Dresden Discussion Paper Series in Economics.

Mohsen Mehrara \& Mohsen Mohaghegh, (2011). Macroeconomic Dynamics in the Oil Exporting Countries: A Panel VAR Study. International Journal of Business and Social Science.

Mutuku C. \& Koech E., (2014). Monetary and Fiscal Policy Shocks and Economic Growth. Journal of World Economic Research.

Nagmi M. Moftah Aimer, (2016). The Effects of Fluctuations of Oil Price on Economic Growth of Libya. Energy Economics Letters, 3(2): 17-29.

Nwoba Martin O. E \& Abah E. O., (2017). Impact of Crude Oil Revenue on Economic Growth in Nigeria. IOSP Journal of Humanities and Social Science (IOSP-JHSS).

Ogunmuyiwa M. S \& Francis Ekone, (2010). Money Supply-Economic Growth Nexus in Nigeria. J SocSci, 22(3):199-204.

Olomola A Philip, (2006). Oil Price Shock and Aggregate Economic Activity in Nigeria. African Economic and Business Review.

Olomola P. A., \& Adejumo A. V., (2006). Oil Price Shock and Macroeconomic Activity in Nigeria. International Research Journal of Finance and Eonomics. 3, 28-34.

Osasohan Agbonlahor, (2014). The Impact of Monetary Policy on the Economy of the United Kingdom: A Vector Error Correction Model (VECM). European Scientific Journal. Vol. 10, No. 16.

Rafiq M. S. \& Mallick S. K., (2008). The Effect of Monetary Policy on Output: A Sign Restriction Approach. Journal of Macroeconomics.

Robert B. Barsky \& Lutz Kilian, (2004). Oil and the Macroeconomy Since the 1970s. Journal of Economic Perspectives Volume 18, Number 4.

Rubina Vohra, (2017). The Impact of Oil Prices on GCC Economies. International Journal of Business and Social Science.

Terfa W. Abraham, (2016). Exchange Rate Policy and Falling Crude Oil Prices: Effect on the Nigerian Stock Market. CBN Journal of Applied Statistics Vol. 7, No. 1 (a).

United Nation Conference on Trade and Development (UNCTAD), (2019). World Economic Situation and Prospects. Sales No. E.19.11.C.1.

Victor Ushahemba Ijirshar, (2015). The Empirical Analysis of Oil Price Revenue and Industrial Growth in Nigeria. African Journal of Business Management.

World Bank (2015). International Monetary Fund. Financial Statistics and Data Files.

World Bank (2017). International Monetary Fund. Financial Statistics and Data Files.

World Bank (2019). International Monetary Fund. Financial Statistics and Data Files. 